\title{
Feasibility, safety, and economic implications of whey-recovered water in cleaning-in-place systems: A case study on water conservation for the dairy industry
}

Yulie E. Meneses ${ }^{*} \dagger^{1}$ and Rolando A. Flores ${ }^{*} \dagger$

${ }^{*}$ Department of Food Science and Technology, and

†The Food Processing Center, University of Nebraska, Lincoln 68588

\begin{abstract}
Water scarcity is threatening food security and business growth in the United States. In the dairy sector, most of the water is used in cleaning applications; therefore, any attempt to support water conservation in these processes will have a considerable effect on the water footprint of dairy products. This study demonstrates the viability for recovering good quality water from whey, a highly pollutant cheese-making byproduct, to be reused in cleaning-in-place systems. The results obtained in this study indicate that by using a combined ultrafiltration and reverse osmosis system, $47 \%$ of water can be recovered. This system generates protein and lactose concentrates, by-products that once spray-dried fulfill commercial standards for protein and lactose powders. The physicochemical and microbiological quality of the recovered permeate was also analyzed, suggesting suitable properties to be reused in the cleaning-in-place system without affecting the quality and safety of the product manufactured on the cleaned equipment. A cost analysis was conducted for 3 cheese manufacturing levels, considering an annual production of 1, 20, and 225 million liters of whey. Results indicate the feasibility of this intervention in the dairy industry, generating revenues of $\$ 0.18, \$ 3.05$, and $\$ 33.4$ million per year, respectively. The findings provide scientific evidence to promote the safety of reuse of reconditioned water in food processing plants, contributing to building a culture of water conservation and sustainable production throughout the food supply chain.
\end{abstract}

Key words: water reconditioning, water optimization, food industry, membrane filtration

Received August 24, 2015.

Accepted January 13, 2016

${ }^{1}$ Corresponding author: yulie@huskers.unl.edu

\section{INTRODUCTION}

Water and food production have such inextricable relation that water scarcity is adversely affecting US agriculture with potential implications for decreasing the food supply and raising food prices (USDA, 2014a). Water shortages and the effect of climate change are risk factors for food security along with the increasing population estimated to reach 9 billion people by 2050 (de Fraiture and Wichelns, 2010). Therefore, water availability for food production will increasingly rely on the sustainable management and use of water in all sectors.

Detailed data on water usage in US dairy processing are not widely available. Nevertheless, published reports from other countries, where water scarcity became a top priority years ago (e.g., Australia), indicate that food industry alone is responsible for $30 \%$ of water consumption in all manufacturing combined (Australian Government Department of Agriculture, Fisheries and Forestry, 2008). Food processing uses only high-quality fresh water as an ingredient and for processing steps such as washing, cooling, heating, transportation, and cleaning. The amount of water used in a particular food processing plant varies depending on the size, efficiency of the equipment, plant layout, and culture. The dairy industry uses 1 to $60 \mathrm{~L}$ of water per $\mathrm{kg}$ of processed milk, mainly for cleaning-in-place (CIP) applications (28\% of total water usage; Rad and Lewis, 2014).

Proper reconditioning (treatment of water intended to be reused) and reuse of wastewater in the food industry is a promising alternative to current practices of discharging these streams in places where they can negatively affect the environment. The authors firmly believe that wastewater recondition, using technologies already available for the food industry, can contribute to conservation initiatives without compromising the safety and the quality of the final product.

Current regulations on food hygiene indicate that only potable water can be used for food contact surfaces and equipment cleaning (FDA, 2013; Codex 


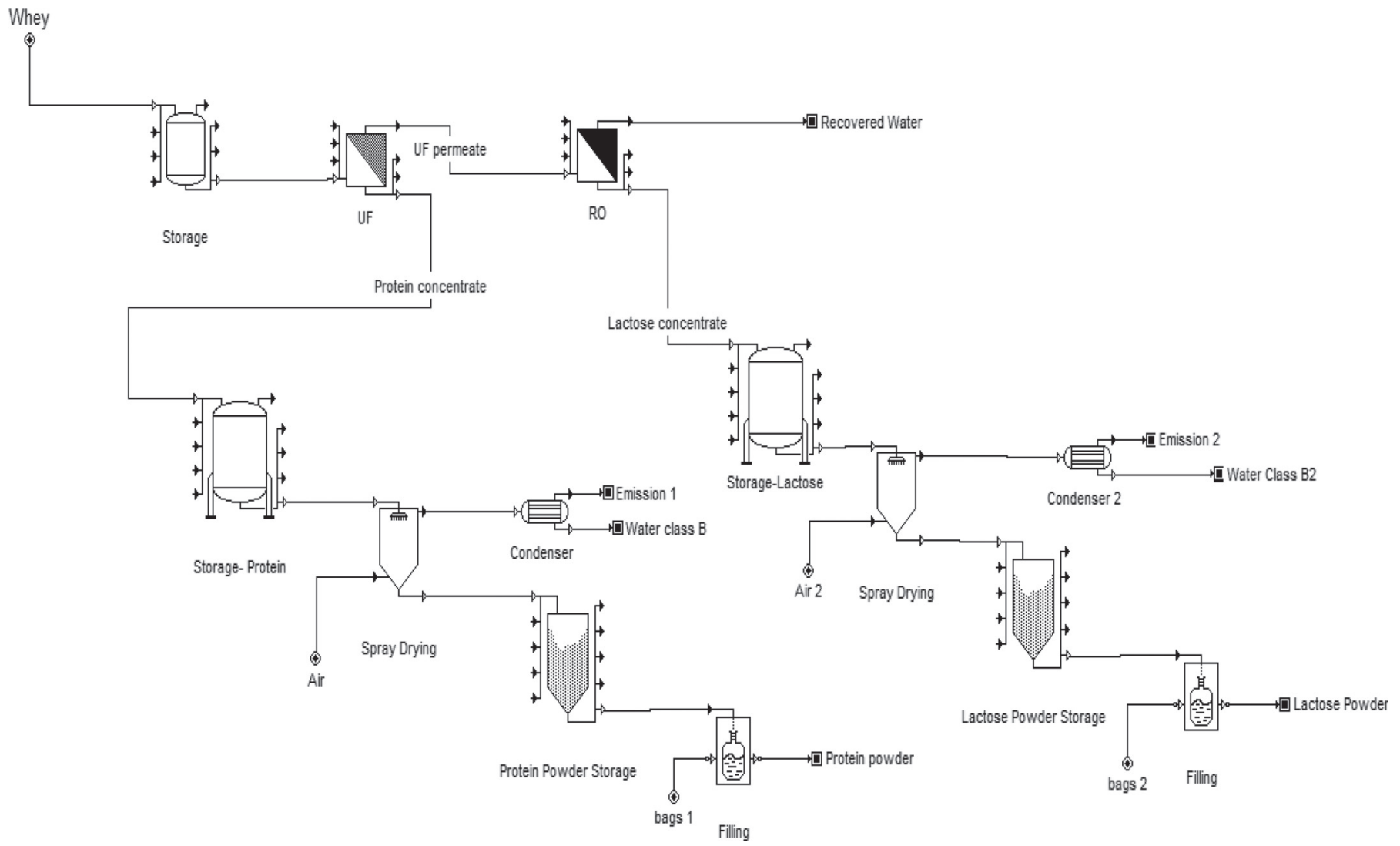

Figure 1. Water recovery system using UF/reverse osmosis (RO) membranes with protein and lactose powder production. Water class B and $\mathrm{B}_{2}$ (condensed water obtained during the spray drying steps), emission 1 and 2 (air leaving the spray drying system).

Alimentarius, 2014), whereas the use of reconditioned water is restricted to initial cleaning of vegetables and fruits, and to the scalding water for meat and poultry (USDA-FSIS, 2012). However, processors are willing to expand the applications for reconditioned water to reduce the consumption of this natural resource and minimize environmental impacts (Casani and Knøchel, 2002).

The lack of published data about the implications of using reconditioned water in food processing plants represents a barrier for water recycling; such information is key to motivate implementation of water conservation initiatives. For that reason, the present study was developed as a holistic approach to provide evidence on the advantages and restrictions of wastewater recondition and reuse; based on the 3 pillars of sustainability (economic, environmental, and social). The main objective was to demonstrate that high quality water can be recovered from cheese whey, with potential for water reuse in CIP operations. First, the performance of the $\mathrm{UF}$ and reverse osmosis (RO) system was evaluated based on permeate flux, pressure changes, volume reduction ratio, flux decline, filtration time, rejection, and retentate solid content. The cleaning efficiency of the recovered water versus potable water was assessed, and finally a cost analysis, for different cheese production scales, was considered to evaluate the feasibility of this proposed approach in the dairy industry. A diagram of the water recovery system and whey powder production is presented in Figure 1.

\section{MATERIALS AND METHODS}

\section{Water Recovery System Configuration and Operating Conditions}

Membrane Filtration. Cheddar cheese whey, produced from standardized whole milk (3.6\% fat), was collected from 3 different cheese batches $(276.5 \pm 11$ $\mathrm{L}$ each time). Whey was collected from a processing plant located in Lincoln, Nebraska, throughout September and October of 2014. Once collected, the whey was immediately fed to the filtration system to avoid additional heating or $\mathrm{pH}$ changes (initial temperature $33 \pm 2^{\circ} \mathrm{C}$ ). The UF and RO filtrations were performed in the model $\mathrm{R}$ pilot scale membrane filtration system 
from GEA Group (Hudson, WI), made entirely of 316 stainless steel. For UF, a semi-permeable polyethersulfone spiral membrane with a molecular weight cut off of 10,000 Da and effective area of $5.4 \mathrm{~m}^{2}$ manufactured by KOCH (Wilmington, MA) was used, with an initial cross-flow rate of $270 \mathrm{~L} / \mathrm{h}$ and a pressure of $0.3 \mathrm{MPa}(3$ bar). For RO, a spiral high rejection (98\%) membrane manufactured by Filmtec membranes (RO-3838/30-FF, Santa Ana, CA) with an effective area of $7.4 \mathrm{~m}^{2}$ was used, applying an initial cross flow of $230 \mathrm{~L} / \mathrm{h}$ and pressure of $3 \mathrm{MPa}$ (30 bar). The filtration system was set up in a concentration mode (retentate returned to the feed tank), and whey was the feed material for UF, whereas the UF permeate was the feed material for the RO membrane. The filtration times were 60 and $40 \mathrm{~min}$ for UF and RO, respectively.

For membrane cleaning, the membrane manufacturers' recommendations were followed using a cleaning regimen that included enzymatic (Ultrasil 67 by Ecolab, St. Paul, MN; $11 \mathrm{~mL} / \mathrm{gal}$ ) and alkaline (Ultrasil 110 Ecolab, $3 \mathrm{~mL} / \mathrm{gal}$ ) washes at $25^{\circ} \mathrm{C}$. Cleaning efficiency was verified by monitoring $\mathrm{pH}$ in final water rinses and by comparing water flow rates before membrane use and after cleaning.

Filtration Efficiency. Several parameters were monitored during filtration for both UF and RO, including solid content, pressure changes, volumetric water permeate, water flux $(\boldsymbol{J w})$, volumetric reduction ratio $(\boldsymbol{V R} \boldsymbol{R})$, rejection $(\boldsymbol{R})$, and water recovery $(\boldsymbol{W} \boldsymbol{R})$. The $J w, V R R, R$, and $W R$ were determined using equations $1,2,3$, and 4 , respectively.

$$
J w=\frac{1}{A_{m}} \cdot \frac{\Delta V t}{\Delta t},
$$

where $A_{m}$ represents the membrane area, $t$ is the time, and $V t$ is the volumetric water permeation at $t$ time.

$$
V R R(t)=\frac{V_{0}}{V_{r(t)}}=\frac{V_{0}}{V_{0}-V_{p(t)}},
$$

where $V_{0}$ is the initial volume of solution, and $V_{r(t)}$ and $V_{p(t)}$ represent the retentate and permeate volume, respectively, at $t$ time.

$$
R_{i}(\%)=\left(1-\frac{C_{p, i}}{C_{R, i}}\right) \cdot 100,
$$

where $C_{p, i}$ and $C_{R, i}$ are the concentration values of the $i$ contaminant measured in permeate and retentate, respectively.

$$
\mathrm{WR}(\%)=\left(\frac{V_{p}}{V_{f}}\right) \cdot 100,
$$

where $V_{p}$ and $V_{f}$ are the volumes measured in permeate and feed, respectively.

Spray Drying. The UF and RO concentrate streams were further spray dried to obtain protein powder and lactose, respectively. The operating conditions for the pilot-scale spray dyer (model T-20, Henningsen, Omaha, NE) were the following: feed flow of $0.16 \mathrm{~L} / \mathrm{min}$, air pressure of $0.17 \mathrm{MPa}$ (25 psig), furnace temperature of $310^{\circ} \mathrm{C}$, and outlet air temperature of $105^{\circ} \mathrm{C}$. Total solid, fat, protein, lactose, water activity, and moisture were evaluated on the powders obtained, following the methods described below.

Analyses. Physicochemical analyses were performed on the initial feed, permeate, and concentrate UF/RO streams. All samples were analyzed using the American Public Health Association recommended methods as described by Rice et al. (2012). Chemical oxygen demand (COD) was digested using the closed reflux method and analyzed on a Perkin Elmer Lambda 25 spectrophotometer (Perkin Elmer, Waltham, MA) while total organic carbon (TOC) was measured on preserved samples using hot persulfate oxidation on an OI Analytical model 1020 TOC analyzer (OI Analytical, College Station, TX). Conductivity was measured using a Fisher Accumet meter (Fisher Scientific, Pittsburgh, PA). Nitrate and nitrite were measured using the Cd-reduction method and ammonia by phenate colorimetry using a Seal Analytical AQ2 discrete chemistry auto analyzer (Seal Analytical, Mequon, WI). All instruments were calibrated immediately before analysis and verified for quality using analysis of laboratory duplicates, fortified blanks, and method blanks.

Proximate composition was determined by measuring TS (Ahn et al., 2014), fat, protein (Nitrogen analyzer, LECO F528, Leco Corp., St. Joseph, MI), and lactose (following the manufacturer's instructions, Sigma-Aldrich MAK017, Sigma-Aldrich, St. Louis, MO). The fat content was determined by adapting the method from Hildebrandt et al. (2011) with a variation on sample preparation, where $20 \mu \mathrm{L}$ of sample were mixed $980 \mu \mathrm{L}$ of Tween $0.5 \%$ solution, then $50 \mu \mathrm{L}$ of the mixture was added to the 96 -well plate.

Finally, aerobic plate counts (APC) and Escherichia coli/coliform testing were performed on the initial whey and RO permeate (recovered water). The APC was performed by plating samples onto Standard Methods Agar (SMA, Acumedia, Lansing, MI) plates, using the spread technique and incubated for $48 \mathrm{~h}$ at $32^{\circ} \mathrm{C}$. The number of viable $E$. coli was determined by plating onto 
E. coli/coliform Petrifilm (3M, St. Paul, MN) following an incubation period of $24 \mathrm{~h}$ at $37^{\circ} \mathrm{C}$.

\section{Biofilm Formation and Water Reuse in CIP}

A CIP regimen was simulated to compare the cleaning effectiveness of the recovered water against potable water. For these experiments, a constant biofilm of Pseudomonas aeruginosa (\# 1063/2783 FPC microbiology laboratory collection; Lincoln, NE) was formed by inoculating the bacteria into a CDC bioreactor (Biosurface Technologies Corp., Bozeman, MT) containing 316 stainless steel coupons, following a standardized procedure (ASTM International, 2012). Contaminated coupons were cleaned following a standardized CIP regimen (described later); cleaned coupons were then sampled for bacterial counts, before (3 coupons) and after (6 coupons) the CIP procedure. Bacteria counts were done by aseptically removing the coupons from the holders, and placing them into 9-mL dilution water tubes to eliminate any planktonic bacteria; coupons were immediately transferred to new 9-mL dilution water tubes and sonicated for $4 \mathrm{~min}$, using an ultrasonic cleaner (model 1210, Bransonic, Danbury, CT). After sonication, tubes were mixed and samples were aseptically plated on SMA using the spread technique and incubated for $48 \mathrm{~h}$ at $37^{\circ} \mathrm{C}$. This experiment was performed 3 times for each water type. Student's $t$-test, assuming unequal variance, was used to compare the mean levels of bacteria enumeration before and after CIP regimen. The significance level of $\alpha=0.05$ was chosen for these tests.

Additionally, scanning electron microscopy images were taken on stainless steel coupons before and after CIP to obtain a closer observation of the biofilm and the effect of the CIP procedure on the surfaces. Karnovsky's fixative solution (EMS, Hatfield, PA) was used to prepare the coupons for scanning electron microscopy imaging. Coupons samples were fixed by $3 \%$ glutaraldehyde in $0.1 M$ phosphate buffer (pH 7.4) and further fixed in $1 \%$ osmium tetroxide in 0.1 $M$ phosphate buffer ( $\mathrm{pH} 7.4$ ) for $1 \mathrm{~h}$. Samples were dehydrated in a graduated ethanol series to $100 \%$. The specimens were subjected to critical point drying in a critical point dryer (Samdri-795, Tousimis, Rockville, $\mathrm{MD})$, coated with gold/palladium in a sputter-coating apparatus (Technics Hummer Sputter Coater, Anatech USA, Union City, CA) to be observed under the scanning electron microscopes (Hitachi S3000N, Hitachi, Tarrytown, NY) at the University of Nebraska-Lincoln Microscopy Core Facility.

Basic water quality analyses including hardness, alkalinity, total and free chlorine as well as APC were performed to monitor and compare the initial quality of the potable and recovered water used on these experiments. For water quality analyses, AquaCheck test strips (HACH, Loveland, CO) were used.

Standardized CIP Regimen. The CIP regimen consisted of an initial 5 -min water rinse $\left(25^{\circ} \mathrm{C}\right)$, a 10 -min wash with caustic cleaner $\left(30 \mathrm{~g} / \mathrm{L}, 65 \pm 1^{\circ} \mathrm{C}\right.$; Spartan, Maumee, $\mathrm{OH})$, followed by a 5 -min water rinse $\left(25^{\circ} \mathrm{C}\right)$, a 10 -min wash with an acidic solution $\left(6 \mathrm{~g} / \mathrm{L}, 65 \pm 1^{\circ} \mathrm{C}\right.$; Spartan), and a final 5 -min water rinse $\left(25^{\circ} \mathrm{C}\right)$.

\section{Cost Analysis}

To provide insight about the investment, revenue, and savings that the proposed water conservation initiative could represent to cheese manufactures, a cost analysis was performed. The entire process was simulated using the SuperPro Designer v9.0 software (Intelligen Inc., Scotch Plains, NJ), including the UF/RO system for water recovery, spray driers for powder production and packing equipment (Figure 1). Membrane cleaning operations were not considered for this analysis. A batch operating mode and an annual operating time of $7920 \mathrm{~h}$ were selected for the analysis. The simulation was performed for 3 cheese production levels $(0.1,1.8$, and 19.5 million $\mathrm{kg} / \mathrm{yr}$ ) generating $3,521,62,815$, and $687,412 \mathrm{~L}$ of whey/d, which correspond to real Cheddar cheese production levels in Wisconsin (USDA, 2013), considering $10 \%$ cheese yield. Input data necessary to run the simulation regarding permeate flux and recovery (permeate/feed) were $16.0 \mathrm{~L} / \mathrm{m}^{2} \cdot \mathrm{h}$ and $73.8 \%$ for $\mathrm{UF}$ and $12.8 \mathrm{~L} / \mathrm{m}^{2} \cdot \mathrm{h}$ and $64.8 \%$ for $\mathrm{RO}$, respectively; all data were obtained from the experimental results generated in this study. To run the material and mass balances, the software requires the composition of a stock mixture (whey); such data were obtained from the proximal analyses performed on whey samples used for each filtration (proximate composition reported later). Software default costs were used for equipment, whereas membrane prices were obtained from manufacturers ( $\$ 65$ and $\$ 44 / \mathrm{m}^{2}$ for UF and RO, respectively). Additional price data for protein and lactose were obtained from published reports (USDA, 2014b), whereas whey cost $(\$ 0.07 / \mathrm{L})$, water $\left(\$ 0.5 / \mathrm{m}^{3}\right)$, energy $(\$ 0.1 /$ $\mathrm{kW} \cdot \mathrm{h})$, steam $(\$ 12 / \mathrm{MT})$, chilled water $(\$ 0.4 / \mathrm{MT})$, and wastewater treatment $(\$ 0.01 / \mathrm{L})$ were obtained from local providers in Lincoln, Nebraska. The total cost estimation includes only items related to direct fix cost (piping, instrumentation, insulation, electrical facilities, and equipment installation). Other costs related to construction, yard improvements, buildings, contractors' fees, and contingency were not included because the proposed intervention is aimed to be applied on 
existing plants, whereas the annual operating cost, working capital, and start-up cost were estimated by the software based on labor, facility, consumables, and utilities costs. Membrane life used for the simulations were 1,000 and 2,000 operating hours for UF and RO, respectively. The estimated annual revenue resulting from the protein and lactose powder sales ( $\$ 87.19$ and $\$ 27.74$ per $25-\mathrm{kg}$ package, respectively) and recovered water $\left(\$ 0.50 / \mathrm{m}^{3}\right)$. The reports generated by the software also include the internal revenue rate (IRR), payback time, and net present value among other financial indicators; these values were determined by the cash flow analysis at the base of a 15 -yr project lifetime, $4 \%$ inflation, direct fix cost outlay of 30,40 , and $30 \%$ for the first $3 \mathrm{yr}$ of the project, respectively. All these economic parameters corresponded to software default values for the version used. Additional information about the model design steps has been described in a book chapter by Petrides and Siletti (2014).

\section{RESULTS AND DISCUSSION}

\section{Process Efficiency}

Different parameters such as permeate water fluxes, volumetric water permeation, pressure changes, TS content were monitored to evaluate the efficiency of the $\mathrm{UF} / \mathrm{RO}$ membrane system for water recovery and for protein and lactose concentration. Results are shown in Figure 2(a), 2(b), and 2(c).

Permeate Water Fluxes and Pressure Changes. Reduction in water fluxes and pressure increments observed in Figure 2(a) are a direct result of concentration polarization and membrane fouling (Luo et al., 2012). Concentration polarization is the reversible accumulation of solute molecules in the solution near the membrane surface, whereas fouling is irreversible (Dickson, 2015). Membrane properties such as pore size and materials play a role on flux decline at the beginning of the filtration; however, as the filtration progresses, the flux decline is controlled by the deposition of foulants (fat, proteins, lactose, and minerals) and their interaction within the membrane (Carić et al., 2000). Whey proteins can easily bind calcium phosphates to form complex organic-inorganic aggregations; thus, when both elements are present in the feed material these complex bridges are formed resulting in flux decline and can be associated with the continued concentration polarization and fouling (Luo et al., 2012). Given that UF removes whey proteins from the feed, the flux decline for the RO filtration can be associated with the continued concentration of lactose in the retentate stream. As shown in Figure 2(a), the final water flux for UF was $4.80 \pm 1.85 \mathrm{~L} / \mathrm{m}^{2} \cdot \mathrm{h}$ at min 60 , whereas for
RO it was $5.71 \pm 0.82 \mathrm{~L} / \mathrm{m}^{2} \cdot \mathrm{h}$ at $\min 40$. The average water flux for the entire UF filtration was $16.03 \pm 1.50$ $\mathrm{L} / \mathrm{m}^{2} \cdot \mathrm{h}$, whereas for $\mathrm{RO}$ the average was $12.80 \pm 1.51$ $\mathrm{L} / \mathrm{m}^{2} \cdot \mathrm{h}$. Both values were used later on as inputs for the cost analysis.

Pressure levels were kept within optimal ranges 0.3 to $0.5 \mathrm{MPa}$ (3-5 bar) for UF and 3 to $4 \mathrm{MPa}(30-40$

a) Permeate water fluxes $\left(J_{w}\right)$ and pressure $(P)$ changes

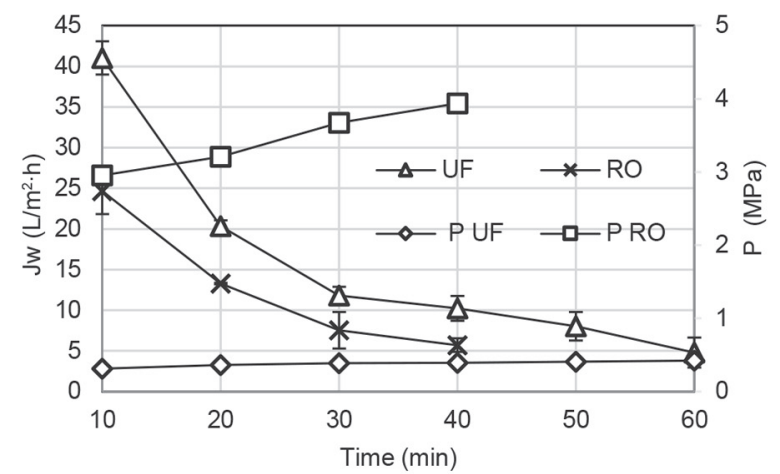

b) Volumetric water permeation

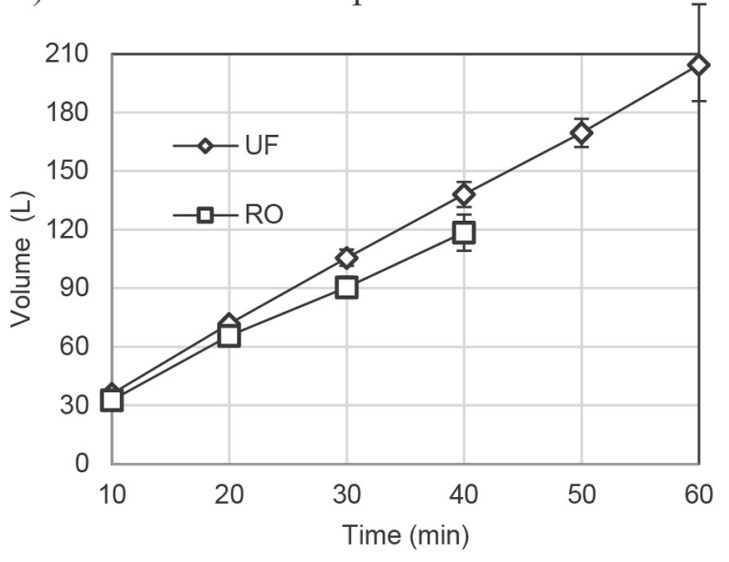

c) Retentate solid content

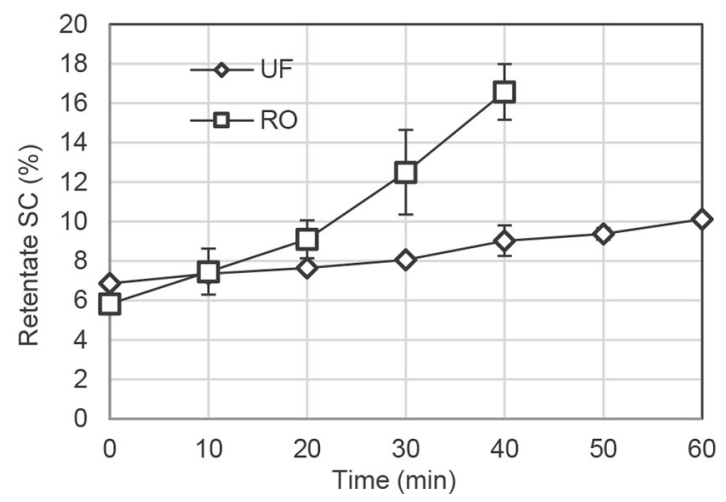

Figure 2. Process efficiency parameter control during filtration. (a) Permeate water fluxes and pressure changes, (b) volumetric water permeation, and (c) retentate solid content (SC). 
bar) for RO, as recommended in the literature (Rektor and Vatai, 2004; Vourch et al., 2008; Luo et al., 2011). In our preliminary observations (data not shown), it was detected that exceeding the upper pressure limit increased the solid content on the permeate (5.6 times higher solid content than when operated within established conditions), which affected the performance of the next filtration. This phenomenon is explained by Luo et al. (2010) as the transport by diffusion of salt ion through the membrane. Diffusion is higher when salt concentration in the membrane is higher, which results from the accumulation of solutes in the feed, resulting in lower permeate fluxes, higher VRR, and higher pressures. Because quality of the recovered water (RO permeate) was of special importance for this study, permeate fluxes and pressure were critical factors to control during filtration processes.

Volumetric Water Permeation. Permeate volumes for UF were always higher than for RO due to the difference in pore size. The final volume recovered for UF was $204.4 \pm 24.78 \mathrm{~L}$, whereas for RO $118.5 \pm 9.21$ $\mathrm{L}$ were collected, representing a recovery of $73.80 \pm$ $6.81 \%$ and $64.77 \pm 7.43 \%$, respectively, with respect to the initial feed material (whey for UF and UF permeate for RO). At the end of the filtration a VRR of $5.47 \pm$ 1.49 and $5.18 \pm 2.91$ were calculated for UF and RO, respectively. The final recovery for the UF/RO filtration system resulted on $47.03 \%$.

Retentate Solid Content. To study the concentration effect on the retentate, the solid content was monitored at different time points during the filtration, as shown in Figure 2(c). Time 0 represents the solid content of the feed material; for UF the solid content on whey was $6.87 \pm 0.02 \%$, whereas for RO the solid content on the UF permeate used as feed was $5.83 \pm$ $0.02 \%$. The final concentrations reached on the retentate streams were $10.11 \pm 0.17 \%$ and $16.57 \pm 1.42 \%$, respectively.

The process efficiency parameters presented above, together with the water quality and microbial analyses, indicated in Table 1 demonstrate that the procedures and operating conditions applied on the UF/RO filtration system described herein, effectively concentrate whey proteins and lactose while allowing water recovery with high quality characteristics. Results shown in Table 1 point out the pollutant potential of whey, which presents high values of conductivity, TOC, and COD due to the presence of protein and lactose. As can be expected, the values of these parameters increased on the retentate streams and decreased on the permeates. However, the initial COD on whey was only reduced by $28.3 \%$ by the UF filtration; this is attributable to the membrane pore size which retains proteins, but is not effective in lactose rejection (Rosenberg, 1995). The combined effect of the RO membrane allows a rejection level of 98.1 and $99.7 \%$ for conductivity and TOC, respectively, to be reached. Similar results have been reported earlier, suggesting recovering water of good quality; nevertheless, implications of water reuse were not assessed (Aydiner et al., 2014). The high initial APC counts $(7 \log \mathrm{cfu} / \mathrm{mL})$ found in whey samples were expected due to the starter bacteria added during cheese manufacture. The UF membrane was able to reduce the bacteria load by $3 \log \mathrm{cfu} / \mathrm{mL}$, and after the RO filtration $1.5 \log \mathrm{cfu} / \mathrm{mL}$ was detected in the permeate. These results are consistent with another water recovery study (Singapore Government, 2002); however, there is also vast literature indicating the use of membranes for complete bacterial removal (Daufin et al., 2001, Madaeni et al., 2011), differences might be due to the membrane type and pressure ranges used during filtration. The water recovered in the first phase of the study (RO permeate) was then used for the CIP experiment described later; therefore, chlorination (1 ppm) within the WHO (2003) and EPA (1999) standards for drinking water was necessary to ensure complete disinfection of the recovered water, for a final APC count of $<1 \log \mathrm{cfu} / \mathrm{mL}$. Initial whey and recovered water were also tested for $E$. coli/coliforms presence, but the results were $<1 \log \mathrm{cfu} / \mathrm{mL}$ in both cases. It is important to highlight that only cheesewhey originated from pasteurized milk was used in the present study; therefore, pathogenic bacteria were not present on the evaluated samples, as demonstrated by the microbial results.

\section{Spray Drying}

The concentrates obtained from the UF/RO filtration system, were spray dried to produce protein powder and lactose powder and to determine the amount of condensed water that can be recovered from this processing step. Table 2 summarizes the values obtained from the proximate analyses for whey, concentrates, and powder samples. The $29.5 \%$ protein content found in the protein powder falls within the Codex Alimentarius (2010) and USDA (2003) standards for whey protein concentrate, as parametric values of $\mathrm{pH}$, moisture, and fat. The reference lactose content for whey powder, according to the Codex Alimentarius, is higher $(61 \%)$ than the $41 \%$ observed in the sample. For the present study, the RO concentrate (mainly lactose) was not mixed with the UF concentrate for the drying step. Therefore, a reduced level of lactose was found in the protein powder, whereas $63.7 \%$ was observed in the lactose powder. These powders presented a final moisture content of 2.13 and $1.55 \%$, respectively. The water removed from the concentrated streams in the 
drying operation, contributed to an overall water recovery of $85.65 \%$ for the entire system (UF/RO and spray drying).

Protein and lactose powders produced from UF/ RO concentrate seem to have potential for commercialization as ingredients, whereas the condensed water (water class $\mathrm{B}$ and $\mathrm{B}_{2}$ ) can be reused for outside plant applications (cleaning trucks, outside floors and walls), or reconditioned by an additional polishing RO step and chlorination to be reused in other operations demanding higher water quality.

\section{Reuse of Whey-Recovered Water in CIP Operations}

The risk of contamination is an important hurdle for water reconditioning and reuse initiatives in processing plants, especially when food-contact surfaces are involved. Thus, the next objective of this study was to determine the cleaning efficiency of chlorinated recovered water obtained from the UF/RO system, when used in CIP operations. Figure 3 shows the results comparing CIP performed with potable water and recovered water; the initial biofilm of Pseudomonas aeruginosa was similar for both treatments (8.6 log cfu/ $\mathrm{cm}^{2}$ ). After the CIP regimen, 0.99 and $1.09 \log \mathrm{cfu} / \mathrm{cm}^{2}$ were detected for potable water and recovered water, respectively. The scanning electron microscopy images (Figure 4) taken before cleaning (A, C) show uniform biofilms for both treatments; after cleaning (B, D), few inactive bacteria debris were observed on the stainless steel surfaces. The Student's $t$-test results did not show significant differences between the cleaning efficiency reached with potable water and recovered water $(P$ value $=0.87 ; \alpha=0.05)$. Besides microbial quality, hardness, alkalinity, $\mathrm{pH}$, and total and free chlorine were tested on potable and recovered water used for the CIP experiments. For parametric values of APC, total and free chlorine were similar for both water types $(<1$ $\log \mathrm{cfu} / \mathrm{mL},<0.5 \mathrm{ppm},<0.5 \mathrm{ppm}$, respectively); $\mathrm{pH}$ showed minimum differences 7.72 and 7.23 for potable and recovered water, respectively. However, important differences on hardness and alkalinity were detected; presenting values of 250 and 25 ppm for potable water and 200 and $40 \mathrm{ppm}$ for recovered water, respectively.

These findings demonstrate that, if properly done, water recovered from whey can be reused in CIP operations without compromising the safety or quality of the final product, while protecting equipment from the negative effects of hard water.

\section{Cost Analysis Results}

The diagram of the integrated UF/RO water recovery system, whey powder production, and packing is 
Table 2. Proximate composition of whey, concentrate, protein, and lactose powders

\begin{tabular}{|c|c|c|c|c|c|c|c|c|}
\hline Parameter & Unit & Whey $^{1}$ & $\mathrm{UF}^{1}$ & $\mathrm{RO}^{1}$ & $\begin{array}{l}\text { Protein } \\
\text { powder }\end{array}$ & $\begin{array}{l}\text { Lactose } \\
\text { powder }\end{array}$ & Codex $^{2}$ & $\mathrm{USDA}^{2}$ \\
\hline $\mathrm{pH}$ & - & 6.56 & 6.49 & 6.35 & & & & \\
\hline Fat & $\%$ & 0.02 & 0.06 & - & 0.08 & 0.02 & 2 & $<10$ \\
\hline Lactose & $\%$ & 5.62 & 9.71 & 15.0 & 41.0 & 63.7 & 61 & NI \\
\hline Total DM & $\%$ & 6.87 & 10.1 & 16.6 & 97.9 & 98.5 & NI & NI \\
\hline Water activity & - & - & - & - & 0.07 & 0.06 & NI & NI \\
\hline
\end{tabular}

${ }^{1}$ Average values obtained from samples collected from the concentrate streams at the end of the filtration. RO $=$ reverse osmosis. NI $=$ not indicated.

${ }^{2}$ Standards for whey protein concentrate.

represented in Figure 1. The cost analysis covers these processing operations for 3 production levels $(1,20$, and 225 million L of whey/yr). Whey is the initial feed for the UF filtration, for which an opportunity cost of $\$ 0.07 / \mathrm{L}$ was considered. The UF permeate was fed to the RO membrane for lactose removal, generating the recovered water intended for reuse in CIP systems. As it can be observed in Figure 1, protein and lactose concentrates were separately spray dried, to obtain protein and lactose powders packed in $25-\mathrm{kg}$ bags. The condensed water generated from the drying step (water class $\mathrm{B}$ and $\mathrm{B}_{2}$ ) was accounted for the water recovery percentage on the entire system; no further treatment was considered for this water type. Still, depending on the desired reuse for this water type, additional chemical (e.g., chlorination) or physical treatment (RO polishing step) could be added. Mass balances for the modeled cheese production levels and the contributions

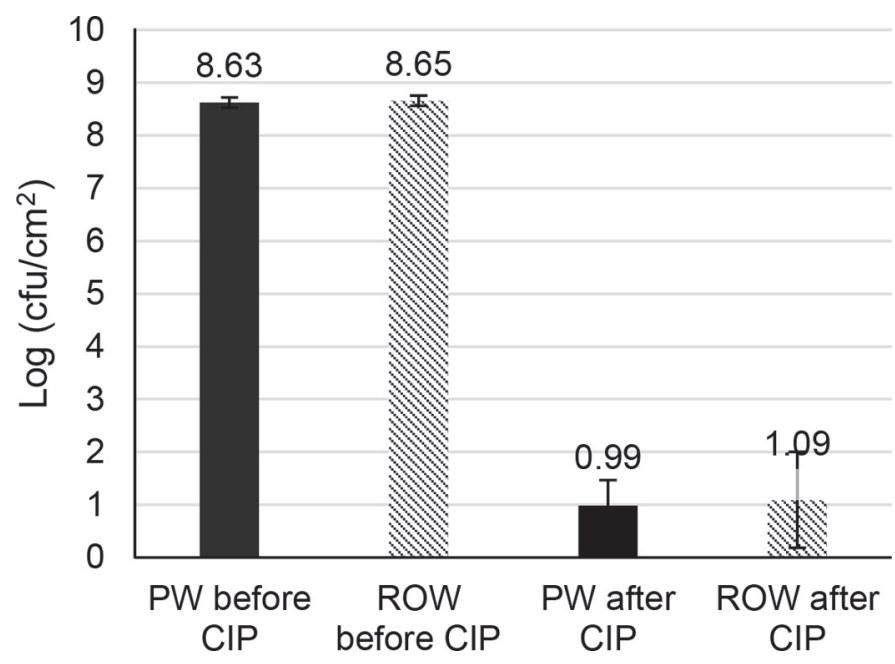

Figure 3. Mean values of Pseudomonas aeruginosa adhesion before and after cleaning in place $(\mathrm{CIP})$ regimen. $\mathrm{PW}=$ potable water; $\mathrm{ROW}$ $=$ recovered water. of each product to the total revenue are presented in Table 3.

The results shown in Table 4 indicate that a total of $\$ 2.04,6.72$, and 56.3 million should be invested to process the total cheese whey generated by the small, medium, and large cheese production scales, respectively. The payback time estimated for the different investments are $10.9,5.17$, and 4.36 yr with an IRR after taxes from 2.42 to $19.5 \%$ for the simulated scenarios. The operating cost resulted in $\$ 0.17, \$ 1.87$, and $\$ 20.1$ million/yr. Finally, the selling of protein powder, lactose protein and recovered water would generate an annual revenue of $\$ 0.18, \$ 3.05$, and $\$ 33.4$ million for small-, medium-, and large-scale plants, respectively. For future studies, it is necessary to include the associated costs to membrane cleaning, thus allowing for a better estimate of the total investment and annual operating cost. These costs were not included herein.

When the cheese whey is not treated for by-product recovery, it is disposed in the municipal wastewater stream, in which case a fee should be paid by the dairy plant. Based on the rate for the state of Nebraska and the COD level on the whey samples, the fee was calculated to be $\$ 40$ per unit disposed (1 unit $=780$ gal). The savings for not paying the municipal fee were not included in the cost analysis discussed earlier; but their effect on the total investment during the payback time is described in Figure 5.

The horizontal axis on Figure 5 represents $10 \%$ increments over the actual wastewater treatment price $(\$ 40 /$ unit disposed), whereas the vertical axis indicates the percentage of the total investment covered by the savings generated during the corresponding payback time, for the 3 described production scales. At point $0 \%$, the water treatment fee is the current cost calculated for Nebraska; using this cost, $23.7 \%$ of the total investment for large-scale production could be covered by the savings generated during the payback time. Wastewater treatment fees are subject to increase due to location, 

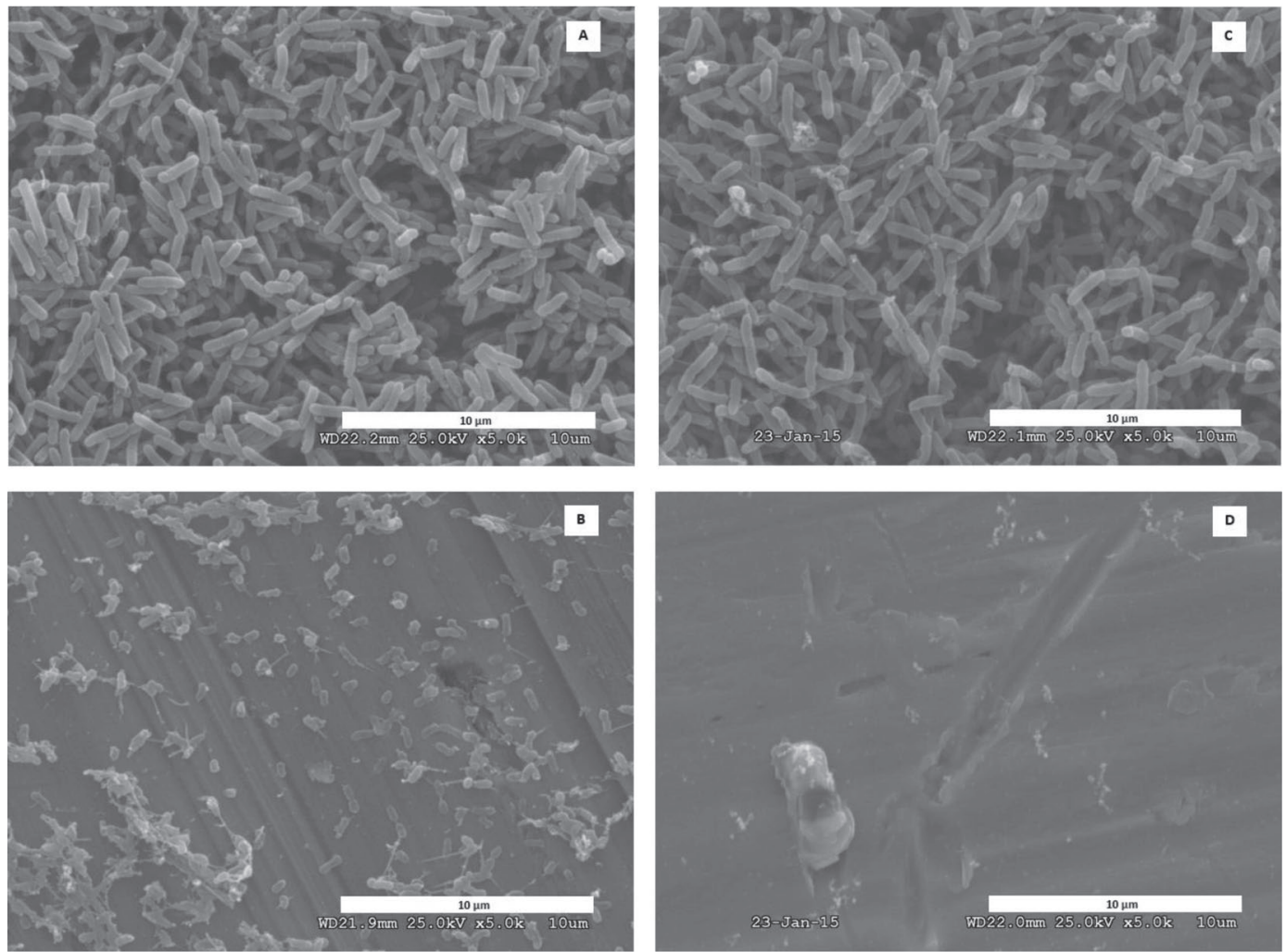

Figure 4. Scanning electron microscopy images of Pseudomonas aeruginosa biofilm before and after cleaning in place. (A and B) potable water; (C and D) recovered water. Resolution $5.0 \mathrm{k}$.

Table 3. Modeled performance and revenue contributions for small, medium, and large cheese manufacturing plants

\begin{tabular}{|c|c|c|c|c|c|}
\hline Streams & $\begin{array}{c}\text { Small } \\
\text { (kg/batch) }\end{array}$ & $\begin{array}{l}\text { Medium } \\
\text { (kg/batch) }\end{array}$ & $\begin{array}{c}\text { Large } \\
\text { (kg/batch) }\end{array}$ & $\begin{array}{l}\text { Revenue } \\
\text { price }(\$)\end{array}$ & $\begin{array}{c}\text { Contribution to } \\
\text { revenue }(\%)\end{array}$ \\
\hline Whey & 3,512 & 62,482 & 683,771 & - & - \\
\hline Protein concentrate & 920 & 16,370 & 179,148 & - & - \\
\hline Lactose concentrate & 912 & 16,231 & 177,627 & - & - \\
\hline Recovered water (permeate RO) & 1,679 & 29,880 & 326,996 & $0.50 / \mathrm{m}^{3}$ & 0.16 \\
\hline Protein powder & 104 & 1,866 & 20,425 & $87.2 /$ entity $^{1}$ & 70.0 \\
\hline
\end{tabular}

${ }^{1}$ Entity $=/$ one $25-\mathrm{kg}$ bag of protein or lactose powder. $\mathrm{RO}=$ reverse osmosis.

Table 4. Economic results of the whey recovered water system for different cheese production levels

\begin{tabular}{lccccc}
\hline $\begin{array}{l}\text { Whey } \\
(\text { million L/yr) }\end{array}$ & $\begin{array}{c}\text { Investment } \\
(\text { million \$) }\end{array}$ & $\begin{array}{c}\text { Revenue } \\
\text { (million \$/yr) }\end{array}$ & $\begin{array}{c}\text { Operating cost } \\
(\text { million \$/yr) }\end{array}$ & $\begin{array}{c}\mathrm{IRR}^{1} \\
(\%)\end{array}$ & $\begin{array}{c}\mathrm{PBT}^{1} \\
(\mathrm{yr})\end{array}$ \\
\hline 1 & 2.04 & 0.18 & 0.17 & 2.42 & 10.9 \\
20 & 6.72 & 3.05 & 1.87 & 15.9 & 5.17 \\
225 & 56.3 & 33.4 & 20.1 & 19.5 & 4.36 \\
\hline
\end{tabular}

${ }^{1} \mathrm{IRR}=$ internal revenue rate; $\mathrm{PBT}=$ payback time. 


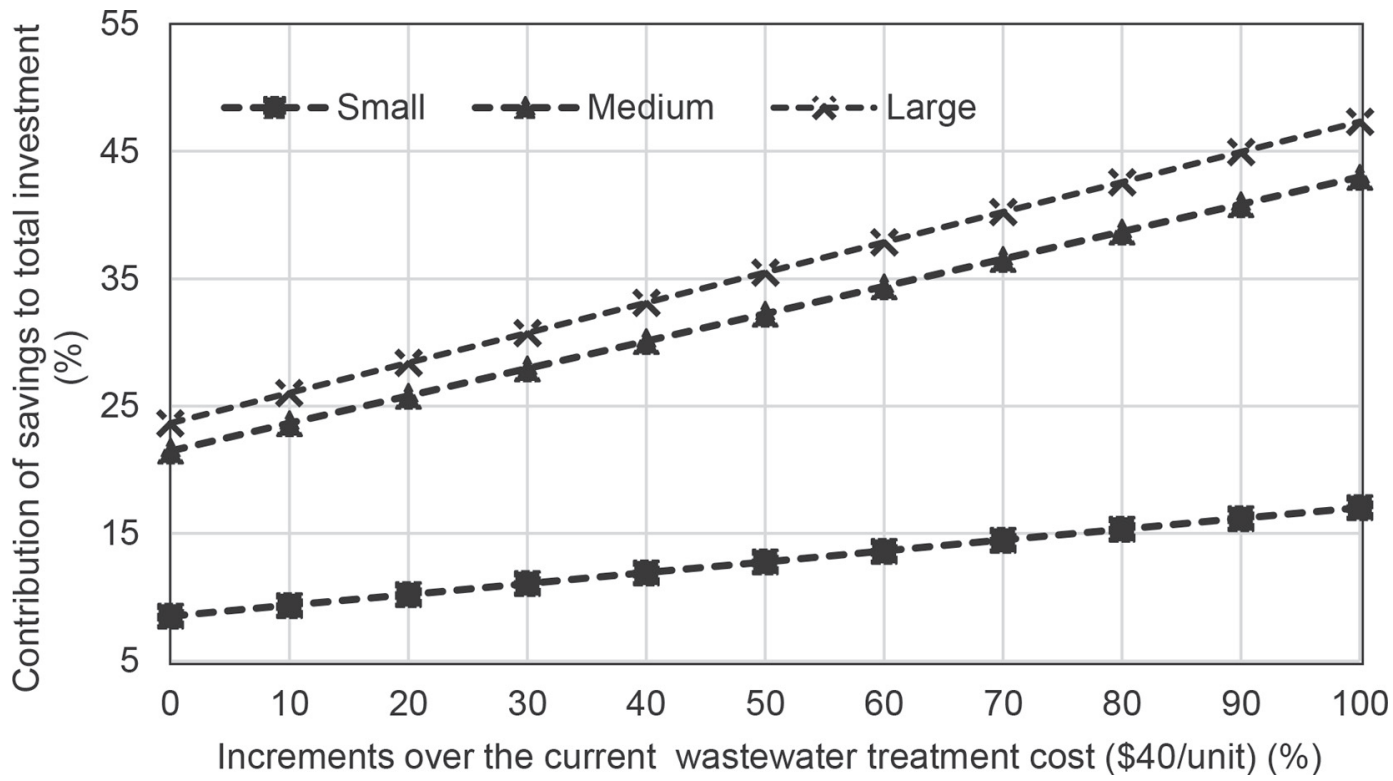

Figure 5. Contribution of savings to the total investment during the payback period, and the effect of wastewater treatment price increments over the current price for 3 cheese production scales.

wastewater specific characteristics, and changes in environmental regulations. If this fee doubles the actual price (100\% increase), the savings would cover as high as $47.3 \%$ of the large-scale investment (Figure 5). The same analogy was followed for small- and medium-scale production.

The contribution that the yearly savings would have over the annual operating cost, after the payback time,

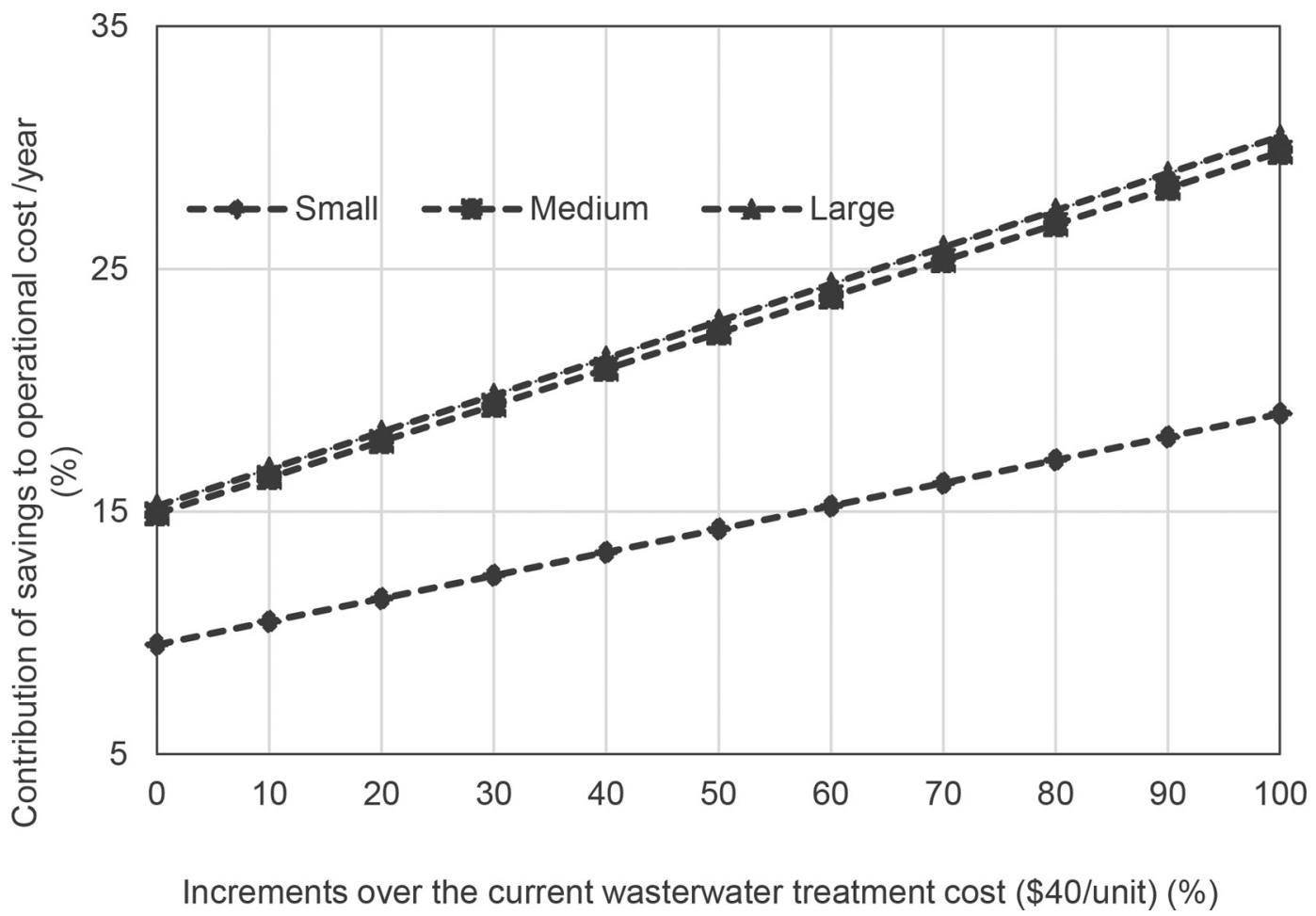

Figure 6. Contribution of savings to the annual operating cost, and the effect of wastewater treatment price increments over the current price for 3 cheese production scales. 
were also evaluated. Likewise, the previous graph, Figure 6 shows the increments on the wastewater treatment fee versus the operating cost percentage that could be covered by the annual savings, for the 3 different scales after the payback time. For medium and large scale, savings contributions were similar, representing 14.9 and $15.2 \%$ of the annual operating cost, respectively, using the current fee price. When the fee increases by $100 \%$, savings contribution increases to 29.8 and $30.5 \%$ for each scale production, respectively. Savings contribution was lower for the small cheese production scale, reaching $9.51 \%$ at the actual fee cost and $19.0 \%$ when the wastewater treatment fee doubles.

Water reconditioning and recycle initiatives in food processing plants reduce water usage and wastewater volumes; consequently environmental effects are reduced and more water is available for the community. Assuming the scenario of a highly efficient large-scale plant, where $1 \mathrm{~L}$ of water is used for every $1 \mathrm{~L}$ of milk processed, then $80 \%$ of its water demand could be supplied by the water conservation initiate proposed herein. Furthermore, the annual domestic water demand of up to 1,540 people in Nebraska (per capita water use 95 $\mathrm{L} / \mathrm{d}$ ) could be satisfied by the potable water that is not consumed in food processing operations.

\section{CONCLUSIONS}

The feasibility of water recovery from whey and reuse in CIP operations has been explored from different perspectives including technological efficiency, safety, and financial needs. The most relevant findings from this study are as follows. A water recovery of $47.03 \%$ was obtained from the UF/RO filtration, whereas recovery of $85.65 \%$ was reached when including the spray-drying step as part of the integrated system. The cleaning efficiency of the water recovered from the UF/RO filtration system is comparable to that of potable water when used in CIP systems. Good quality lactose and protein powders with commercial value were obtained from concentrated streams. The proposed intervention is economically feasible for different cheese production scales, and water conservation initiatives in food industries have potential for sustainable production, without competing with the community for the use of natural resources. The results obtained represent an important contribution to fill the gap of information related to the implications of water reuse and recycling for inside-plant applications. In this respect, complementary future work will focus on describing possible post-reconditioning treatment contamination of the recovered water based on a risk assessment approach, and a broader evaluation of the environmental effects based on the life cycle assessment methodology.

\section{ACKNOWLEDGMENTS}

This study was possible thanks to the support of the Robert B. Daugherty Water for Food Institute at the University of Nebraska, Lincoln.

\section{REFERENCES}

Ahn, J. Y., D. Y. Kil, C. Kong, and B. G. Kim. 2014. Comparison of oven-drying methods for determination of moisture content in feed ingredients. Asian-australas. J. Anim. Sci. 27:1615-1622.

ASTM International. 2012. Standard test methods for Quantification of Pseudomonas aeruginosa Biofilm Grown with High Shear and Continuous Flow using CDC Biofilm Reactor E2562-12. ASTM International, West Conshohocken, PA.

Australian Government Department of Agriculture, Fisheries and Forestry. 2008. Australian Food Statistics 2007. Accessed Jul. 28 , 2015. http://www.agriculture.gov.au/ag-farm-food/food/ publications/afs.

Aydiner, C., U. Sen, S. Topcu, D. Ekinci, A. D. Altinay, D. Y. Koseoglu-Imer, and B. Keskinler. 2014. Techno-economic viability of innovative membrane systems in water and mass recovery from dairy wastewater. J. Membr. Sci. 458:66-75.

Carić, M. Đ., S. D. Milanović, D. M. Krstić, and M. N. Tekić. 2000 Fouling of inorganic membranes by adsorption of whey proteins. J. Membr. Sci. 165:83-88.

Casani, S., and S. Knøchel. 2002. Application of HACCP to water reuse in the food industry. Food Contr. 13:315-327.

Codex Alimentarius. 2010. Codex Standard for Whey Powders Codex Stan 289-1995 Accessed Jul. 15, 2015. http://www.fao.org/ docrep/015/i2085e/i2085e00.pdf.

Codex Alimentarius. 2014. General principles of food hygiene CAC/ RCP 1-1969. Accessed Jul. 28, 2015. http://www.fao.org/fao-whocodexalimentarius/standards/list-standards/en/.

Daufin, G., J. P. Escudier, H. Carrère, S. Bérot, L. Fillaudeau, and M. Decloux. 2001. Recent and emerging applications of membrane processes in the food and dairy industry. Food Bioprod. Process. 79:89-102.

de Fraiture, C., and D. Wichelns. 2010. Satisfying future water demands for agriculture. Agric. Water Manage. 97:502-511.

Dickson, K. H. A. J. M. 2015. Membrane Processing for Dairy Ingredient Separation. John Wiley and Sons Ltd., New York, NY.

EPA. 1999. Chlorine Disinfection EPA 832-F-062. United States Environmental Protection Agency, Washington, DC.

FDA. 2013. FDA Food Code 2009: Chapter 5-Water, Plumbing \& Waste. Accessed Nov. 27, 2013. http://www.fda.gov/food/ guidanceregulation/retailfoodprotection/foodcode/ucm186352. htm\#part5-1.

Hildebrandt, A., I. Bickmeyer, and R. P. Kühnlein. 2011. Reliable Drosophila body fat quantification by a coupled colorimetric assay. PLoS ONE 6:e23796.

Luo, J., W. Cao, L. Ding, Z. Zhu, Y. Wan, and M. Y. Jaffrin. 2012 Treatment of dairy effluent by shear-enhanced membrane filtration: The role of foulants. Separ. Purif. Tech. 96:194-203.

Luo, J., L. Ding, B. Qi, M. Y. Jaffrin, and Y. Wan. 2011. A two-stage ultrafiltration and nanofiltration process for recycling dairy wastewater. Bioresour. Technol. 102:7437-7442.

Luo, J., L. Ding, Y. Wan, P. Paullier, and M. Y. Jaffrin. 2010. Application of NF-RDM (nanofiltration rotating disk membrane) module under extreme hydraulic conditions for the treatment of dairy wastewater. Chem. Eng. J. 163:307-316.

Madaeni, S. S., M. Yasemi, and A. Delpisheh. 2011. Milk sterilization using membranes. J. Food Process Eng. 34:1071-1085.

Petrides, D., and C. Siletti. 2014. Batch process simulation. Pages 199-230 in Batch Processing: Modeling and Design. 1st ed. U. Diwekar, ed. CRC Press, Boca Raton, FL.

Rad, S. J., and M. J. Lewis. 2014. Water utilization, energy utilization and waste water management in the dairy industry: A review. Int. J. Dairy Technol. 67:1-20. 
Rektor, A., and G. Vatai. 2004. Membrane filtration of Mozzarella whey. Desalination 162:279-286.

Rice, E. W., L. Bridgewater, American Public Health Association, American Water Works Association, and Water Environment Federation. 2012. Standard Methods for the Examination of Water and Wastewater. American Public Health Association, Washington, DC.

Rosenberg, M. 1995. Current and future applications for membrane processes in the dairy industry. Trends Food Sci. Technol. 6:12-19.

Singapore Government. 2002. Water Reclamation Study expert panel review and Findings. Accessed Jan. 15, 2014. http://www.pub. gov.sg/water/newater/NEWaterOverview/Documents/review.pdf.

USDA. 2003. Specifications for Dry Whey Protein Concentrate. Agricultural Marketing Service, USDA, Washington, DC. Accessed May 15, 2015. https://www.ams.usda.gov/sites/default/files/ media/drywheyconcentrate.pdf.

USDA. 2013. 2013 Wisconsin Agricultural Statistics. Accessed May 15 2015. http://www.nass.usda.gov/Statistics_by_State/Wisconsin/ Publications/Annual_Statistical_Bulletin/bulletin2013_web.pdf.
USDA. 2014a. California Drought 2014: Farm and Food Impacts. Accessed Aug. 21, 2015. http://ers.usda.gov/topics/in-the-news/ california-drought-2014-farm-and-food-impacts.aspx.

USDA. 2014b. Dry Whey Products-Lactose-Central and West Region Annual report. Accessed May 15, 2015. https://www.marketnews. usda.gov/mnp/da-report-config?category=DryWheyProducts.

USDA-FSIS. 2012. Poultry Chiller Makeup Water. Accessed Mar. 28, 2014. http://www.fsis.usda.gov/wps/wcm/connect/a404035016b1-4d29-b602-15200f943f51/6410.3.pdf?MOD=AJPERES

Vourch, M., B. Balannec, B. Chaufer, and G. Dorange. 2008. Treatment of dairy industry wastewater by reverse osmosis for water reuse. Desalination 219:190-202.

WHO. 2003. Chlorine in drinking-water. Accessed Sep. 15, 2014 http://www.who.int/water_sanitation_health/dwq/chlorine.pdf. 